\title{
Identification of polymorphic microsatellite loci for the endangered Kagu (Rhynochetos jubatus) by high-throughput sequencing
}

\author{
Bernhard C. Stoeckle • Jörn Theuerkauf - Sophie Rouys • \\ Roman Gula - Almudena Lorenzo - Christophe Lambert • \\ Tatjana Kaeser $\cdot$ Ralph Kuehn
}

Received: 21 September 2010/Revised: 24 January 2011/ Accepted: 25 July 2011/Published online: 13 August 2011

(C) The Author(s) 2011. This article is published with open access at Springerlink.com

\begin{abstract}
We used 454 pyro-sequencing to establish microsatellite markers for the endangered Kagu (Rhynochetos jubatus), a bird endemic to New Caledonia. We screened 52,583 reads to identify 60 microsatellites candidates and established 12 polymorphic loci. The number of alleles per locus ranged from 2 to 15 , the observed heterozygosity from 0.046 to 0.818 , the expected
\end{abstract}

Communicated by M. Wink.

B. C. Stoeckle · T. Kaeser · R. Kuehn

Unit of Molecular Zoology, Chair of Zoology,

Department of Animal Science,

Technische Universität München,

Hans-Carl-von-Carlowitz-Platz 2,

85354 Freising, Germany

e-mail: kuehn@wzw.tum.de

J. Theuerkauf $(\bowtie) \cdot$ R. Gula

Museum and Institute of Zoology, Polish Academy of Sciences,

Wilcza 64, 00-679 Warsaw, Poland

e-mail: jtheuer@miiz.eu

R. Gula

e-mail: rgula@miiz.eu

\section{S. Rouys}

Conservation Research New Caledonia, BP 2549, 98846 Nouméa Cedex, New Caledonia

e-mail: sophierouys@lagoon.nc

\section{A. Lorenzo}

Parc Zoologique et Forestier, Direction de l'Environnement, BP 3718, 98846 Nouméa Cedex, Province Sud, New Caledonia e-mail: almudena.lorenzo@province-sud.nc

\section{Lambert}

Chargé de mission pour la recherche et le développement durable, Secrétariat Général, BP L1, 98849 Nouméa Cedex, Province Sud, New Caledonia

e-mail: christophe.lambert@ province-sud.nc heterozygosity from 0.046 to 0.906 , and the polymorphic information content (PIC) from 0.043 to 0.875 . Two loci showed significant deviation from the Hardy-Weinberg equilibrium, while we did not detect any linkage between loci. The panel of microsatellites identified and characterized in this study will be useful to assess the genetic constitution of wild Kagu populations, which is necessary for effective conservation and breeding strategies of captive birds.

Keywords Rhynochetidae - Rhynochetos jubatus . Next generation sequencing - Short tandem repeats

\section{Zusammenfassung}

Identifizierung von polymorphen Mikrosatelliten-Markern für den gefährdeten Kagu (Rhynochetos jubatus) mit Hilfe von Mega-Sequenzierung

Mit Hilfe der 454 Pyro-Sequenzierung haben wir Mikrosatelliten-Marker für den gefährdeten Kagu (Rhynochetos jubatus), einen endemischen Vogel Neukaledoniens etabliert. 52.583 Sequenzen wurden analysiert und 60 Kandidaten für Mikrosatelliten identifiziert, wobei 12 Loci sich als polymorph erwiesen. Die Anzahl der Allele pro Locus lag zwischen 2 und 15, die beobachtete Heterozygotie zwischen 0,046 und 0,818 , die erwartete Heterozygotie zwischen 0,046 und 0,906 und der polymorphe Informationsgehalt (PIC) zwischen 0,043 und 0,875. Alle Loci befanden sich im Kopplungsgleichgewicht. Zwei Mikrosatellitensysteme zeigten eine signifikante Abweichung vom Hardy-Weinberg-Gleichgewicht. Die in dieser Studie identifizierten und charakterisierten Mikrosatelliten tragen dazu bei, die genetische Struktur der freilebenden KaguPopulationen zu erfassen. Diese Kenntnis ist für effektive 
Erhaltungsstrategien der Wildpopulationen als auch für das Zuchtmanagement von in Gefangenschaft gehaltenen Vögeln erforderlich.

\section{Introduction}

The flightless Kagu (Rhynochetos jubatus) is an endemic, endangered bird of New Caledonia (Hannecart and Létocart 1980; IUCN 2010). The larger Kagu populations are restricted to rain forests that are usually far from human settlements (Hunt 1996), as the bird is vulnerable to dog predation (Hunt et al. 1996). Other invasive mammals (rats, cats, pigs), which are widespread throughout the Kagu range (Rouys and Theuerkauf 2003), have also been considered to be important threats to Kagus (Létocart and Salas 1997). However, there were few documented cases of predation by other predators than dogs (Gula et al. 2010). Because of this focus on the impact of invasive species, the possible threat related to the genetic variability of Kagu populations has received little attention. However, for over a century, the Kagu population has been declining (Warner 1948). The only survey of the Kagu population over the whole island, undertaken in 1992, indicated as few as 650 wild Kagus (Hunt 1996), separated into subpopulations. These findings led to the suggestion that the Kagu might have gone through a genetic bottleneck. Assessing the genetic constitution of a population requires an effective analytical tool such as polymorphic microsatellites, which provides conservationists with the current levels of genetic variability, needed for effective conservation in situ (restocking, reintroduction, prioritizing different sites) and ex situ (breeding strategies of captive birds), as well as for research on reproductive systems (Theuerkauf et al. 2009a, b). Since 2003, we have therefore attempted to develop informative microsatellite markers for the Kagu.

Our early attempts using cloning from genomic libraries following the procedure described in Estoup et al. (1993) were unfortunately not successful. By screening 1,500 recombinant clones, a total of 15 positive clones was detected and 7 clones for sequencing were selected after pre-analyses according to Geist et al. (2003). Four clones contained microsatellites suitable for primer design. Two primer pairs amplified products of predicted size at low rates of stuttering but the PCR products showed no microsatellite variability. In their review, Zane et al. (2002) described a low frequency of microsatellites in avian genomes, which explains the low success rate of detecting microsatellites using cloning procedures. The efficiency in detecting microsatellites using next generation sequencing has been proved by Abdelkrim et al. (2009), Allentoft et al. (2009), Santana et al. (2009), Csencsics et al. (2010), and
Stoeckle and Kuehn (2011). We therefore used 454 pyrosequencing to establish polymorphic microsatellite markers for the Kagu. This article reports the first identification and characterisation of microsatellites, which now allows the assessing of the genetic constitution of Kagu populations.

\section{Methods}

We collected down feathers from the rump of 20 wild Kagus of a population in the Parc Provincial de la Rivière Bleue, south New Caledonia $\left(22^{\circ} 3-12^{\prime} \mathrm{S}, 166^{\circ} 33-46^{\prime} \mathrm{E}\right)$, from 2004 to 2009 . We plucked out about 10 feathers without touching their roots, placed them in hermetically sealed bags, and stored them at $4^{\circ} \mathrm{C}$. Additionally, we sampled 2 Kagus from other populations: a feather sample from 1 wild-caught Kagu of a population near Poindimié in the northeast of New Caledonia $\left(20^{\circ} 56^{\prime} \mathrm{S}, 165^{\circ} 20^{\prime} \mathrm{E}\right)$, and a tissue sample (stored in 95\% alcohol) from 1 deceased captive-bred Kagu (parents were wild-caught) of the Parc Zoologique et Forestier in Nouméa, New Caledonia $\left(22^{\circ} 15^{\prime} \mathrm{S}, 166^{\circ} 27^{\prime} \mathrm{E}\right)$.

We isolated DNA from the tissue sample following Hogan et al. (1994). The feather DNA was isolated according to Segelbacher (2002). The DNA of the tissue sample was subjected to 454 sequencing at the GS-FLX LAB (Eurofins MWG Operon, Ebersberg, Germany). A $1 / 16$ plate generated 52,583 reads $(13.7 \mathrm{Mb})$ with an average length of $261 \mathrm{bp}$. A single Fasta file containing all reads was screened for di-, tri- and tetra-nucleotide repeats using MSATCOMMANDER (Faircloth 2008) with at least six repeats for di-nucleotide and four for tri- and tetranucleotide microsatellites. We detected 349 loci (104 di-nucleotides, 175 tri-nucleotides, 70 tetra-nucleotides) suitable for primer design with Primer3 software (Rozen and Skaletsky 2000) using the default settings. Subsequently, we ignored loci with extremely too long and compound interrupted repeat stretches as described by Opgenoorth (2009). In order to detect identical sequences within the remaining set of potential microsatellites, we compared the sequences by similarity and additionally aligned them with the software GENEIOUS v4.7 (Drummond et al. 2009). Finally, out of 231 potential loci (65 di-nucleotides, 117 tri-nucleotides, 49 tetra-nucleotides), we randomly ordered 60 primer pairs flanking 25 di-, 25 tri- and 10 tetra-nucleotide from Biomers (Ulm, Germany). The fluorescent labeling was done according to Schuelke (2000) with a universal M13 Primer. We used gradient PCR-protocol $\left(50-60^{\circ} \mathrm{C}\right)$ (Mastercycler Gradient, Eppendorf, Germany) to test the 60 primer pairs on DNA extracted from 3 individuals and obtained amplified products of expected size with low rates of intense stuttering for 30 of the 60 microsatellite markers. 
For genotyping, we used the DNA of the 22 sampled individuals. Polymerase chain reactions (PCRs) were performed in a total volume of $15 \mu \mathrm{l}$ with the following components: $25 \mathrm{ng}$ of genomic DNA, $0.2 \mu \mathrm{M}$ of each reverse primer, and the M13 universal primer (fluorescently labeled with 6-FAM), $0.05 \mu \mathrm{M}$ of each forward primer, $0.2 \mathrm{mM}$ of each dNTP (Solis BioDyne), 1.5-3 mM $\mathrm{MgCl}_{2}$ (Table 1), $1 \times$ PCR buffer (Solis BioDyne), and 0.5 U Taq DNA Polymerase (FIREPol ${ }^{\circledR}$, Solis BioDyne). For PCR amplification, we used a thermal cycler (Mastercycler Gradient, Eppendorf, Germany) with the following PCR profile: initial denaturation at $94^{\circ} \mathrm{C}$ for $5 \mathrm{~min}, 30$ cycles of $30 \mathrm{~s}$ at $94^{\circ} \mathrm{C}, 30 \mathrm{~s}$ at the primer specific annealing temperature (Table 1), $45 \mathrm{~s}$ at $72^{\circ} \mathrm{C}$, followed by eight cycles of $30 \mathrm{~s}$ at $94^{\circ} \mathrm{C}, 45 \mathrm{~s}$ at $53^{\circ} \mathrm{C}, 45 \mathrm{~s}$ at $72^{\circ} \mathrm{C}$, and a final elongation step at $72^{\circ} \mathrm{C}$ for $10 \mathrm{~min}$. PCR products were separated on $6 \%$ polyacrylamide gels on an $\mathrm{ABI}$ Prism 377 automated sequencer (Perkin Elmer) and scored in reference to a ROX standard (79-540 bp) by GENESCAN $^{\circledR}$ 3.1.2 and GENOTYPER ${ }^{\circledR} 2.5$ software (Applied Biosystems, Foster City, CA, USA). We repeated the PCR amplification and genotyping of DNA extracts from

Table 1 Characteristics of 12 microsatellite loci for the Kagu (Rhynochetos jubatus): locus designation, GenBank accession nb., repeat motif, primer sequences, annealing temperature $\left(T_{\mathrm{A}}\right), \mathrm{MgCl}_{2}$ feathers three times as the use of this material as a source of DNA can lead to genotyping errors, mainly allelic dropout (Taberlet and Luikart 1999; Segelbacher 2002). We used GENEPOP 4.0 (Rousset 2008) to calculate the number of alleles, to generate allele frequencies, expected $\left(H_{\mathrm{E}}\right)$ and observed $\left(H_{\mathrm{O}}\right)$ heterozygosities, and to test for linkage disequilibrium and deviations from Hardy-Weinberg equilibrium (frequency of alleles in a large, interbreeding population characterized by random mating, mendelian inheritance, and the absence of migration, mutation, and selection). For calculating the polymorphic information content (PIC), we used the EXCEL MICROSATELLITE TOOLKIT (Park 2001). MICRO-CHECKER 2.2.3 (Van Oosterhout et al. 2004) was used to test the dataset for genotyping errors and for the presence of null alleles.

\section{Results and conclusion}

Out of 30 microsatellite loci tested on the 22 Kagus, 18 were monomorphic and 12 were polymorphic with $2-15$

concentration, number of observed alleles $\left(N_{\mathrm{A}}\right)$, allele size range (including length of M13 primer), PIC values, level of observed $\left(H_{\mathrm{O}}\right)$ and expected $\left(H_{\mathrm{E}}\right)$ heterozygosity per locus

\begin{tabular}{|c|c|c|c|c|c|c|c|c|c|c|}
\hline Locus & $\begin{array}{l}\text { GenBank } \\
\text { accession } \\
\text { nb. }\end{array}$ & Repeat motif & Primer sequences $\left(5^{\prime}-3^{\prime}\right)$ & $\begin{array}{l}T_{\mathrm{A}} \\
\left({ }^{\circ} \mathrm{C}\right)\end{array}$ & $\mathrm{MgCl}_{2}$ & $N_{\mathrm{A}}$ & $\begin{array}{l}\text { Allelic size } \\
\text { range (bp) }\end{array}$ & PIC & $H_{\mathrm{O}}$ & $H_{\mathrm{E}}$ \\
\hline RTY19 & HM565115 & $(\mathrm{ATT})_{15}$ & $\begin{array}{l}\text { F: GGGGAAACCATTTTTCATCTC } \\
\text { R: CCACAGCGTTGTTTCTTGTG }\end{array}$ & 60 & 3.0 & 15 & $222-243$ & 0.875 & 0.8182 & 0.9059 \\
\hline RTY21 & HM565116 & $(\mathrm{AT})_{14}$ & $\begin{array}{l}\text { F: CAACTTTCTGCAACTGCTCTG } \\
\text { R: CTGGGCCGTGATTCTTACAC }\end{array}$ & 57 & 3.0 & 5 & $186-200$ & 0.648 & 0.5909 & 0.7188 \\
\hline RTY35 & HM565117 & $(\mathrm{AC})_{8}$ & $\begin{array}{l}\text { F: TGGTGGCACACTCCAAAATA } \\
\text { R: GCACAACACCTCTGTGCCTA }\end{array}$ & 60 & 3.0 & 2 & $152-172$ & 0.370 & 0.5909 & 0.5021 \\
\hline RTY37 & HM565118 & $(\mathrm{GT})_{8}$ & $\begin{array}{l}\text { F: CAGGCTGAGAATGCCAAAAT } \\
\text { R: AGTACCCTGGAGTGGTTTGC }\end{array}$ & 60 & 3.0 & 3 & $187-191$ & 0.541 & 0.4545 & 0.6353 \\
\hline RTY38 & HM565119 & $(\mathrm{CT})_{8}$ & $\begin{array}{l}\text { F: CAGCTGCAAGATTTCCCATA } \\
\text { R: GGACCCTGATGAACAACACA }\end{array}$ & 60 & 1.5 & 2 & $195-197$ & 0.406 & 0.7273 & 0.5317 \\
\hline RTY40 & HM565120 & $(\mathrm{GT})_{8}$ & $\begin{array}{l}\text { F: GAATGGGTTTTGAGGTATTGGA } \\
\text { R: TCAACACAAATGTGGAAGTGTTT }\end{array}$ & 60 & 3.0 & 2 & $167-169$ & 0.290 & 0.4545 & 0.3594 \\
\hline $\mathrm{RTY}_{47^{\mathrm{a}}}$ & HM565121 & $(\mathrm{GT})_{7}$ & $\begin{array}{l}\text { F: CGACTACAGCTTACATAATCCTCCT } \\
\text { R: GGGTAGGGCACAGACAGAAA }\end{array}$ & 54 & 1.5 & 2 & $263-265$ & 0.305 & 0.0455 & 0.3837 \\
\hline RTY54 & HM565122 & $(\mathrm{GCCT})_{7}$ & $\begin{array}{l}\text { F: ACTACAGCTTGTTAGAAATTCCTTC } \\
\text { R: GTGCCAACTTCCAAAACATCG }\end{array}$ & 55 & 3.0 & 2 & $186-190$ & 0.043 & 0.0455 & 0.0455 \\
\hline RTY55 & HM565123 & $(\mathrm{AAAT})_{9}$ & $\begin{array}{l}\text { F: TTTCACAAAGACTCCTCAGTATAAG } \\
\text { R: AGCAGCCTATTTCATTTTGTCC }\end{array}$ & 55 & 3.0 & 4 & $241-253$ & 0.651 & 0.8182 & 0.7199 \\
\hline RTY56 & HM565124 & $(\mathrm{AAAC})_{5}$ & $\begin{array}{l}\text { F: CCTGCCCAGAGGTAGGAAG } \\
\text { R: GGTCCTCACCAGGAAGAAAAC }\end{array}$ & 55 & 3.0 & 3 & $177-185$ & 0.514 & 0.8182 & 0.6057 \\
\hline${\text { RTY } 57^{\mathrm{a}}}$ & HM565125 & $(\mathrm{ATCC})_{15}$ & $\begin{array}{l}\text { FTGTCTTCTTTCTGTCTGTGTGTC } \\
\text { R: CGCTTGTTTCATGCTAAGACG }\end{array}$ & 55 & 3.0 & 5 & $154-178$ & 0.644 & 0.5454 & 0.7104 \\
\hline RTY58 & HM565126 & $(\mathrm{ATCT})_{4} \ldots(\mathrm{ATCT})_{13}$ & $\begin{array}{l}\text { F: CGACTACAGCTCCCTATAAATCAC } \\
\text { R: GACTCCTCTTCCTCCACCC }\end{array}$ & 55 & 3.0 & 4 & $159-175$ & 0.648 & 0.7273 & 0.7199 \\
\hline
\end{tabular}

\footnotetext{
${ }^{a}$ Loci that deviated from Hardy-Weinberg equilibrium after Bonferroni correction, $P=0.004$
} 
alleles, with an average of 4.2 alleles per locus (Table 1). Observed heterozygosity values ranged from 0.046 to 0.818 , and those for expected heterozygosity from 0.046 to 0.906. Regarding the PIC values, 7 microsatellites are highly informative (PIC $>0.5$ ), 4 are reasonably informative $(0.5>$ PIC $>0.25)$, and 1 is only slightly informative (PIC $<0.25$ ) by using the classification of Botstein et al. (1980) (Table 1). By genotyping 22 individuals, we detected a total of 49 different alleles.

We detected no linkage between locus pairs in the tested Kagu samples. The test on Hardy-Weinberg equilibrium for each locus revealed deviations in two loci (RTY47 and RTY57) after Bonferroni correction (Table 1). This deviation might be caused by population substructure of the 22 selected samples. MICRO-CHECKER did not detect any genotyping error (e.g. scoring error) among the dataset, although possible null alleles were likely at the locus RTY47. The markers identified in this study will allow the assessing of the life history, mating strategies and sexual selection patterns of Kagus. We also expect that the markers will improve the current captive breeding programmes in order to maintain a maximum genetic diversity. Furthermore, this study demonstrated that the next-generation sequencing is a powerful technique to isolate microsatellites of species for which conventional methods were unsuccessful.

Acknowledgments This study was part of the research project "Impact of introduced mammals and habitat loss on endemic birds of New Caledonia", done in cooperation with the Province Sud (New Caledonia), which issued all permits for this study, and financed by the Province Sud, Technische Universität München (Germany), Polish Ministry of Science and Higher Education (Grant 2P04F 001 29), Loro Parque Fundación (Spain), Conservation des Espèces et Populations Animales (France), La Fondation Nature et Découvertes (France), Fonds für bedrohte Papageien (Germany), StrundenPapageien-Stiftung (Germany), and Zoologische Gesellschaft für Arten- und Populationsschutz (Germany). We thank M. Broersen, C. Chatreau, P. de Pous, D. Dingemans, S. Duijns, B. Michielsen, E. Minnema, L. Nijdam, H. Theuerkauf, J. van Dijk, M. van Opijnen, J. Wardenaar, N. Petit, and many others for their help during field work; C. Matton and M. Bonzon for taking samples from captive Kagus; M. Bauer, H. Saar, A. Holzwarth and A. Batel for their help during laboratory work; and anonymous reviewers for useful comments.

Open Access This article is distributed under the terms of the Creative Commons Attribution Noncommercial License which permits any noncommercial use, distribution, and reproduction in any medium, provided the original author(s) and source are credited.

\section{References}

Abdelkrim J, Robertson BC, Stanton J-AL, Gemmell NJ (2009) Fast, cost-effective development of species-specific microsatellite markers by genomic sequencing. BioTechniques 46:185-192
Allentoft M, Schuster S, Holdaway R, Hale M, McLay E, Oskam C, Gilbert T, Spencer P, Willerslev E, Bunce M (2009) Identification of microsatellites from an extinct moa species using highthroughput (454) sequence data. BioTechniques 46:195-200

Botstein D, White RL, Skolnick M, Davis RW (1980) Construction of a genetic linkage map in man using restriction fragment polymorphisms. Am J Hum Genet 32:314-331

Csencsics D, Brodbeck S, Holderegger R (2010) Cost-effective, species-specific microsatellite development for the endangered dwarf bulrush (Typha minima) using next-generation sequencing technology. J Hered 101:789-793

Drummond AJ, Ashton B, Cheung M, Heled J, Kearse M, Moir R, Stones-Havas S, Thierer T, Wilson A (2009) Geneious v4.7 (http://www.geneious.com/)

Estoup A, Solignac M, Harry M, Cornuet JM (1993) Characterisation of (GT)n (CT) $n$ microsatellites in two insect species: Apis mellifera and Bombus terrestris. Nucleic Acids Res 21:1427-1431

Faircloth BC (2008) MSATCOMMANDER: detection of microsatellite repeat arrays and automated, locus-specific primer design. Mol Ecol Resour 8:92-94

Geist J, Rottmann O, Schröder W, Kuehn R (2003) Development of microsatellite markers for the endangered freshwater pearl mussel Margaritifera margaritifera L. (Bivalvia: Unionoidea). Mol Ecol Notes 3:444-446

Gula R, Theuerkauf J, Rouys S, Legault A (2010) An audio/video surveillance system for wildlife. Eur J Wildl Res 56:803-807

Hannecart F, Létocart Y (1980) Oiseaux de Nouvelle-Calédonie et des Loyautés, vol. 1. Editions Cardinalis, Nouméa, NouvelleCalédonie

Hogan BLM, Beddington R, Costantini F, Lacy E (1994) Manipulating the mouse embryo: a laboratory manual. Cold Spring Harbor Laboratory Press, Woodbury, New York

Hunt GR (1996) Environmental variables associated with population patterns of the kagu Rhynochetos jubatus of New Caledonia. Ibis 138:778-785

Hunt GR, Hay R, Veltman CJ (1996) Multiple kagu Rhynochetos jubatus deaths caused by dog attacks at a high-altitude study site on Pic Ningua, New Caledonia. Bird Conserv Int 6:295-306

IUCN (2010) IUCN Red List of Threatened Species. Version 2010.3 (http://www.iucnredlist.org). Downloaded on 20 Sept 2010

Létocart Y, Salas M (1997) Spatial organisation and breeding of kagu Rhynochetos jubatus in Rivière Bleue Park, New Caledonia. Emu 97:97-107

Opgenoorth L (2009) Identification and characterization of microsatellite marker in the tetraploid Juniperus tibetica Kom. using next generation sequencing. Conserv Genet Resour 1:253-255

Park SDE (2001) Trypanotolerance in West African cattle and the population genetic effects of selection. $\mathrm{PhD}$ thesis, University of Dublin

Rousset F (2008) Genepop'007: a complete re-implementation of the genepop software for Windows and Linux. Mol Ecol Resour 8:103-106

Rouys S, Theuerkauf J (2003) Factors determining the distribution of introduced mammals in nature reserves of the southern province, New Caledonia. Wildl Res 30:187-191

Rozen S, Skaletsky H (2000) Primer3 on the WWW for general users and for biologist programmers. Methods Mol Biol 132:365386

Santana Q, Coetzee M, Steenkamp E, Mlonyeni O, Hammond G, Wingfield M, Wingfield B (2009) Microsatellite discovery by deep sequencing of enriched genomic libraries. BioTechniques 46:217-223

Schuelke M (2000) An economic method for the fluorescent labelling of PCR fragments. Nature Biotechnol 18:233-234

Segelbacher G (2002) Noninvasive genetic analysis in birds: testing reliability of feather samples. Mol Ecol Notes 2:367-369 
Stoeckle BC, Kuehn R (2011) Identification of 18 polymorphic microsatellite loci in the spruce bark beetle Ips typographus (Coleoptera: Scolytidae) using high-throughput sequence data. Eur J Entomol 108:169-171

Taberlet P, Luikart G (1999) Non-invasive genetic sampling and individual identification. Biol J Linn Soc 68:41-55

Theuerkauf J, Rouys S, Mériot JM, Gula R (2009a) Group territoriality as a form of cooperative breeding in the flightless kagu of New Caledonia. Auk 126:371-375

Theuerkauf J, Rouys S, Mériot JM, Gula R, Kuehn R (2009b) Cooperative breeding, mate guarding, and nest sharing in two parrot species of New Caledonia. J Ornithol 150:791797

Van Oosterhout C, Hutchinson WF, Wills DPM, Shipley P (2004) MICRO-CHECKER: software for identifying and correcting errors in microsatellite data. Mol Ecol Notes 4:535-538

Warner DW (1948) The present status of kagu, Rhynochetos jubatus, on New Caledonia. Auk 65:287-288

Zane L, Bargelloni L, Patarnello T (2002) Strategies for microsatellite isolation: a review. Mol Ecol 11:1-16 